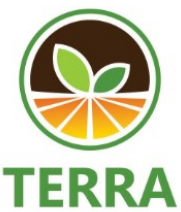

Journal of Land Restoration

\title{
Effect of Vermicompost Dose to K Content in_Leaves and Growth of Corn (Zea mays, L) on Ultisol
}

\author{
Nunung Nurjanah ${ }^{1}$, Riwandi $^{2 *}$, Hasanudin ${ }^{2}$ \\ ${ }^{1}$ Agroecotechnology Department, University of Bengkulu \\ ${ }^{2}$ Soil Science Department, University of Bengkulu (Corresponding author) \\ e-mail: riwandi@unib.ac.id
}

\begin{abstract}
The objectives of this research were to obtain an optimum dose of vermicompost fertilizer to the nutrient levels of $K$ in the leaves, K uptake, and corn growth in ultisols. This research were held in September until November 2018, which has been implemented in green house and the Laboratory of Soil Science, Faculty of Agriculture, University of Bengkulu. The research used Completely Randomized Design (CRD) with a single factor consisting of 7 levels of treatment and three replicates i.e. $0,2.5,5.0,7.5,10.0,12.5$, and 15.0 ton $\mathrm{ha}^{-1}$. The results showed that the optimum dose of vermicompost fertilizer 5.71 ton ha ${ }^{-1}$, resulting in leave $K$ content of $0.59 \%, 9.5$ ton vermicompost ha ${ }^{-1}$, producing the absorption of $K$ leaves $31 \mathrm{~kg} \mathrm{ha}^{-1}, 9.59$ ton vermicompost ha-1, producing a plant height $160.7 \mathrm{~cm}$, 10.2 ton vermicompost ha $a^{-1}$, producing the fresh stover weight $27,561.2 \mathrm{~kg} \mathrm{ha}^{-1}$, 98.9 ton vermicompost ha ${ }^{-1}$, producing the dry stover weight $5,675.5 \mathrm{~kg} \mathrm{ha}^{-1}$, and 9.5 tons vermicompost ha ${ }^{-1}$, producing root dry weight $1,156 \mathrm{~kg} \mathrm{ha}^{-1}$.
\end{abstract}

Keywords: corn, potassium, Ultisol, vermicompost

\section{INTRODUCTION}

Ultisol is one of the type of soil in Indonesia, with a widespread 45,794,000 ha (Prasetyo \& Suriadikarta, 2006). Ultisol has great potential to be developed into farmland to increase corn production to achieve a target of corn self-sufficiency program by the government. One of the provinces that can reach this program is the Province of Bengkulu, because it has a land area of 26,997 ha (Wibawa, 2014).

Ultisol has problems in physical, chemical, and biological properties i.e. in soil physical properties such as compactness, sensitive to erosion, and low waterholding capacity. Soil chemical properties such as low of $\mathrm{pH}$, available $\mathrm{N}, \mathrm{P}, \mathrm{K}$, ion exchange capacity, and base saturation \%age, but also Al saturation \% age, iron ( $\mathrm{Fe}$ ) and Mangan ( $\mathrm{Mn})$ content are high, so its potentially to poison plants. Then soil biological properties such as low organic matter and poor microorganism population Soil survey Staff 2014). The problems of the soil properties can decrease plant growth (Kasno \& Rostam, 2013). One way to overcome the problem of the soil properties can be carried out inputs using vermicompost fertilizer. Vermicompost is an organic fertilizer produced through the process of decomposting organic matter using the activity of earthworm which capable of improving soil physical, chemical, and biological properties able to maintain and increase agricultural land productivity in a long period as well as preserving natural resources without damaging the environment (Roidah \& Ida, 2013).

The advantages of vermicompost i.e. (1) to increase the absorption of plant nutrients, (2) increase soil water storage, (3) there are beneficial microorganism in many quantities, (4) to improve soil structure (Sallaku et al., 2009). Vermicompost also contains a lot of nutrients available in plants and increases soil porosity, soil aeration, humidity, and control soil erosion to aid in the buffer of toxins for plants and increase plant growth (Sheela \& Khimiya, 2013). Corn cultivation organically needs to be done, because organic corn plant growth is more optimal than the cultivation in inorganic ways (Tauri, 2014).

Corn is a cereal plant that includes the second important food crops in Indonesia in addition to rice. The volume of corn imports is higher than that of its exports is due to the demand for high corn, but it cannot be fulfilled by domestic corn production (Kementerian Pertanian, 2015). One of the limiting factors of corn development in Indonesia is the limited productive land due to land function and causing low soil fertility such as Ultisol (Ayunda, 2014). 
The corn plant needs more essential nutrients such as N, P, K, but this nutrient in the land of Ultisol is very little in existence (Sirappa \& Razak, 2010). Potassium (K) is one of the essential nutrients needed by corn plants in a considerable amount, but the soil $\mathrm{K}$ content is very small so as not able to increase leaf $\mathrm{K}$ content, absorption $\mathrm{K}$ leaf so that the growth of corn plants is not optimal (Pradipta et al., 2014).

The objective of this research were to obtain the optimum dose of vermicompost fertilizer for leaf $\mathrm{K}$ content, $\mathrm{K}$ uptake, and corn-growth of the Bisi-2 in Ultisol .

\section{MATERIAL AND METHOD}

This research was conducted from September until November 2018 at the Green House, Faculty of Agriculture. Analysis of soil and plants was carried out at the Soil Science Laboratory, Faculty of Agriculture, Bengkulu University. This research used Compeletely Randomized Design (CRD) with single factor, consisting of 7 levels of treatment i.e. $\mathrm{V}_{0}=0$ tons $\mathrm{ha}^{-1}$ or equivalent to $0 \mathrm{~g}$ polybags $\mathrm{s}^{-1}, \mathrm{~V}_{1}=2.5$ tons $\mathrm{ha}^{-1}$ or equivalent to $25 \mathrm{~g}^{\text {polybags }}{ }^{-1}, \mathrm{~V}_{2}=5.0$ tons $\mathrm{ha}^{-1}$ or equivalent to $50 \mathrm{~g}^{-1}$ polybags ${ }^{-1}, \mathrm{~V}_{3}=7.5$ tons $\mathrm{ha}^{-1}$ or equivalent to $75 \mathrm{~g}^{-1}$ polybags ${ }^{-1}, \mathrm{~V}_{4}=10.0$ tons $\mathrm{ha}^{-1}$ or equivalent to $100 \mathrm{~g}^{-1}$ polybags ${ }^{-1}, \mathrm{~V}_{5}=12.5$ tons $\mathrm{ha}^{-1}$ or equivalent to $125 \mathrm{~g}$ polybags $^{-1}$, and $\mathrm{V}_{6}=$ 15.0 tons $\mathrm{ha}^{-1}$ or equivalent to $150 \mathrm{~g} \mathrm{polybags}^{-1}$. Each treatment was repeated three replicates so that there were 21 experimental units. Soil media used, one week before planting were given vermicompost fertilizer according to the treatment dose, and Urea based fertilizer $175 \mathrm{~kg} \mathrm{ha}^{-1}$ is equivalent to $1.75 \mathrm{~g} \mathrm{polybags}^{-1}$, SP36 $100 \mathrm{~kg} \mathrm{ha}^{-1}$ is equivalent to $10 \mathrm{~g}_{\text {polybags }}{ }^{-1}$ and $\mathrm{KCl} 50 \mathrm{~kg} \mathrm{ha}^{-1}$ is equivalent to $0.5 \mathrm{~g}_{\text {polybags }}{ }^{-1}$. Vermicompost, Urea, SP36, and $\mathrm{KCl}$ fertilizer is mixed evenly with the soil media and put into a polybag and watered to the field capacity water content. The seeds used in this study were Bisi-2 corn. Planting is done by immersing two Bisi-2 corn seeds into $\pm 2 \mathrm{~cm}$ soil media that has been mixed with Furadan $3 \mathrm{G}$ as much as 5 grains each polybag further covered with soil. Maintenance carried out in this study includes: watering, replanting, and controlling weeds. Watering was done every day in the afternoon except for rain until the vegetative phase of plant growth. Replanting was done one week after planting by replacing dead plants. Weed control was done conventionally by pulling the weeds that grow.

Harvesting was done by opening a polybag, then separating between roots and plants. The plants' roots are cleaned by spraying the roots of the plants with water until they cleaned. After that, the plants were weighed to get fresh weights. Furthermore, the plants and roots were dried in the oven until the weight is constant at a temperature of $70-80{ }^{\circ} \mathrm{C}$ and weighed to get the plant's dry stover weight. The observed variables consist of the main variables and the supporting variables. The main variables observed were leaf $\mathrm{K}$ content (\%) analyzed when the final vegetative and measured by wet combution method (Sulaeman et al., 2005, Page et al. 1982), K uptake (g polybags ${ }^{-1}$ ) with the formula $\mathrm{K} \times$ dry weight of plants (Sulaeman et al., 2005, Page et al., 1982). Plant height was measured at the end of vegetative use of a rolling meter by measuring from the base of the stem to the highest leaf tip. Fresh stover weight, dry stover weight, and root dry weight using two decimal digital scales at the end of vegetative. As for the supporting variables consisting of initial soil analysis which includes total $\mathrm{N}$ (Kjeldhal method), available P (Bray-1 method), exchangeable $\mathrm{K}\left(\mathrm{NH}_{4} \mathrm{OAC} 1 N \mathrm{pH} 7\right)$, Organic $\mathrm{C}$ (Walkley \& Black method), CEC $\left(\mathrm{NH}_{4} \mathrm{OAC} 1 N \mathrm{pH}\right.$ 7), and $\mathrm{pH}\left(\mathrm{H}_{2} \mathrm{O}\right)$ with 1: 2.5 (soil weight/water volume). Vermicompost analysis consists of total N, P, $\mathrm{K}$ (Wet combustion method), and Organic C (Walkley \& Black). Rainfall data ( $\mathrm{mm})$, air humidity (\%), air temperature (C) were taken from Badan Meteorologi Klimatologi dan Geofisika, Bengkulu. Experimental data were statistically analyzed by the $F$ test at a level of alpha 5\%. Soil and plant variables that showed significant differences, then proceed with orthogonal polynomial methods to determine the relationship between independent and non-independent variables.

\section{RESULT AND DISCUSSION}

Preliminary soil analysis showed that soil $\mathrm{pH}$ of the 5.3 was classified as an acid soil. The optimal soil $\mathrm{pH}$ level for maize ranges from 5.6 to 6.2 (Riwandi et al., 2014). Soil organic C content of $4.31 \%$ is high, the cation exchange capacity (CEC)

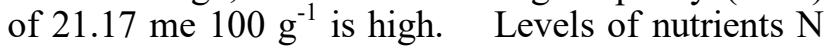
are $1.31 \%, \mathrm{P} 0.92 \%, \mathrm{~K} 0.30 \%$, and organic $\mathrm{C}$ of vermicompost $9.54 \%$. Average and daily rainfall in September: $23.9 \mathrm{~mm}$ with seven rainy days, October: $18.5 \mathrm{~mm}$ with 17 rainy days, and November 29.2 $\mathrm{mm}$ with 23 rainy days. The average humidity in September: $81.5 \%$, October $84.4 \%$, and November $86.9 \%$. The average temperatures in September are $26.7^{\circ} \mathrm{C}$, October $26.0{ }^{\circ} \mathrm{C}$, and November $26.6^{\circ} \mathrm{C}$. Corn plants require open spaces and light. The height of the suitable place for corn is $0-1300 \mathrm{~m}$ above sea level. The air temperature needed for the growth of corn plants is $23-27{ }^{\circ} \mathrm{C}$. The ideal rainfall for maize plants is between $200-300 \mathrm{~mm}$ month $^{-1}$ or $800-1200 \mathrm{~mm}$ year $^{-1}$ (Riwandi et al., 2014). At the time of the research, the Bisi-2 corn plant grew well. The average plant height in the first week was $17.60 \mathrm{~cm}$, the average plant height for the third week was $82.33 \mathrm{~cm}$, and the average plant height for the fifth week was $160.7 \mathrm{~cm}$. When the plants were 21 days after planting, the plants were attacked by plant-disturbing organisms 
(OPT) such as grasshoppers and fire ants, but not to the point of endangering the plants.

Based on variance analysis of the data showed that all observation variables had significant $(\mathrm{P} \leq$ 0.05 ) on leaf $\mathrm{K}$ content, $\mathrm{K}$ uptake, plant height, fresh stover weight, dry stover weight, and root dry weight, due to the dose of vermicompost fertilizer (Table 1).

Table 1 . Summary variance analysis of vermicompost dose effect on leave $\mathrm{K}$ content, $\mathrm{K}$ uptake, and corn growth

\begin{tabular}{lccc}
\hline Variable & F-calculated & F-table5\% & CV (\%) \\
\hline Leaf K content & $8,47^{*}$ & 2,85 & 6,82 \\
K uptake & $7,31^{*}$ & 2,85 & 27,45 \\
Plant height & $4,36^{*}$ & 2,85 & 10,89 \\
Fresh stover & $8,28^{*}$ & 2,85 & 23,29 \\
weight & & & \\
Dry stover & $15,34^{*}$ & 2,85 & 23,11 \\
$\begin{array}{l}\text { weight } \\
\text { Root dry }\end{array}$ & $3,57^{*}$ & 2,85 & 36,07 \\
weight & & & \\
\hline
\end{tabular}

* significant at level alpha 5\%

\section{Leaf_K content}

Analysis of quadratic regression between vermicompost doses and leaf_K content showed a noticeable effect, indicated by a coefficient value of $\mathrm{R}^{2}$ of 0.11 .

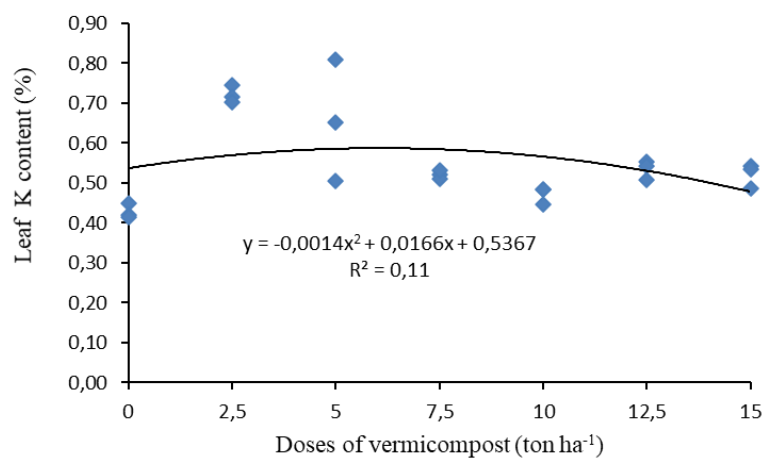

Fig 1. Relationship between doses of vermicompost fertilizer and leaf $\mathrm{K}$ content

The optimum dose of vermicompost fertilizer of 5.71 tons ha ${ }^{-1}$ produces a maximum leaf $\mathrm{K}$ content of $0.59 \%$, while a similar study conducted by Havlin et al.(1999) verify the dose of vermicompost fertilizer used is the same as this study 5.71 tons $\mathrm{ha}^{-1}$ produces $0.03 \%$, it can be said that the results for this
$\mathrm{K}$ level are better than the K-level results done by Havlin et al. (1999). Can be seen from the results of the study showed that the provision of vermicompost fertilizer has a real effect on the nutrient levels of $\mathrm{K}$ leaves to increase nutrient levels $\mathrm{K}$ leaves of corn plants Bisi-2. The importance of the increase of $\mathrm{K}$ in plants because $\mathrm{K}$ has a role in opening and closing the stomata because it affects the turgor of guard cells with increased concentration of $\mathrm{K}+$ in cells. Whereas if $\mathrm{K}$ levels are low in plants will cause many processes that do not go well, for example, the accumulation of carbohydrates, showing symptoms of weak plant stems so that plants easily collapse (Salisbury \& Ross 1995).

\section{K uptake}

Analysis of quadratic regression between vermicompost dose and $\mathrm{K}$ uptake showed a real relationship, as evidenced by the coefficient of determination value of 0.255 .

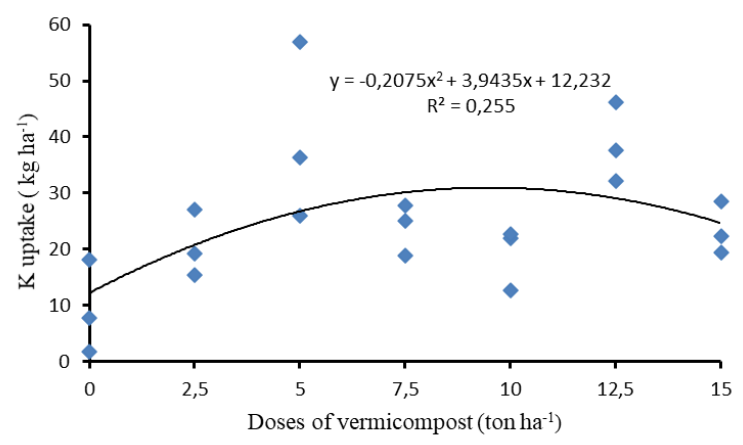

Figure 2. Relationship between doses of vermicompost fertilizer and $\mathrm{K}$ uptake

The optimum dose of vermicompost fertilizer of 9.5 tons $\mathrm{ha}^{-1}$, resulting in the optimum $\mathrm{K}$ uptake of corn crops of $31 \mathrm{~kg} \mathrm{ha}^{-1}$. A similar study conducted by Libra (2018) showed that administering a dose of vermicompost fertilizer of 5 tons ha ${ }^{-}$ ${ }^{1}$ only produced an absorption of $0.24 \mathrm{~g}$. The study results showed that the provision of vermicompost fertilizer has a real effect on the absorption of nutrients $\mathrm{K}$ leaves of corn crops. The dose of vermicompost fertilizer affects the absorption of $\mathrm{K}$ corn crops because vermicompost helps in the formation of carbohydrates to strengthen the stems and improve corn crops' quality (Gardner_et al. 1991).

\section{Plant height}

Analysis of quadratic regression between vermicompost dose and plant height had a noticeable effect, showing that the coefficient value of $R^{2}$ was 0.5569 . 


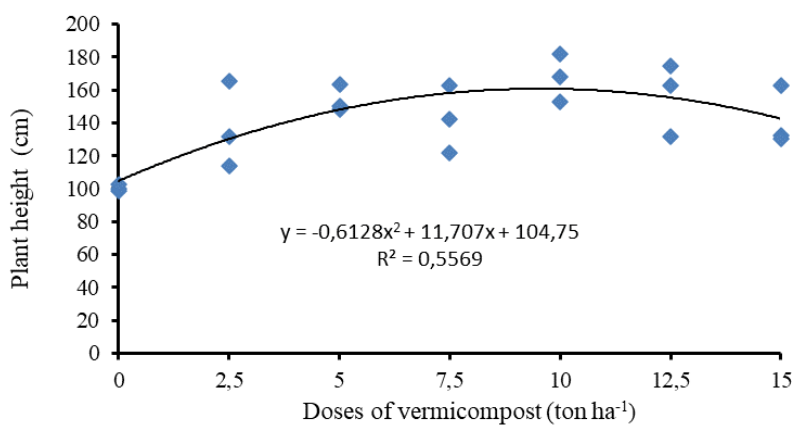

Figure 3. Relationship between doses of vermicompost fertilizer and plant height

The optimum dose of vermicompost 9.59 ton $\mathrm{ha}^{-1}$ produces an optimum plant height of $160.7 \mathrm{~cm}$. In general, the height of plants in this study is still low compared to the high potential of plants based on the description of corn crop varieties BISI-2 is $232 \mathrm{~cm}$. In contrast, the height of plants in this study reached $160.7 \mathrm{~cm}$. The results of a similar study conducted by Riwandi (2015) showed that administering a dose of compost fertilizer 10 tons $\mathrm{ha}^{-1}$ produces a plant height of $100.50 \mathrm{~cm}$ at moderately fertile soil.

\section{Fresh stover weight}

Analysis of quadratic regression between vermicompost dose and fresh stover weight can be seen from the coefficient value of $\mathrm{R}^{2}$ of $0.585 \%$.

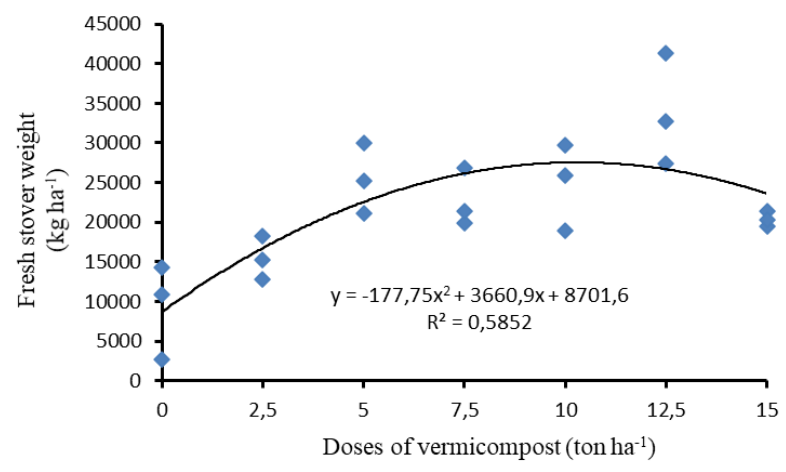

Figure 4. Relationship between doses of vermicompost fertilizer and fresh stover weight

The optimum dose of vermicompost 10.2 tons $\mathrm{ha}^{-1}$ produces an optimum wet weight of $27,561.2 \mathrm{~kg}$ $\mathrm{ha}^{-1}$. A similar study conducted by Syahputra (2007) showed that the dose of vermicompost as much as 2.5 tons ha ${ }^{-1}$ resulted in a wet weight of $25.52 \mathrm{~g}$, if the dose of vermicompost fertilizer given is the same as 10.2 tons ha ${ }^{-1}$ produces a fresh stover weight of
$112,449.6 \mathrm{~kg} \mathrm{ha}^{-1}$, it can be said that by administering a dose of vermicompost 10.2 tons $\mathrm{ha}^{-1}$ the results of this study are better than the results of research conducted by Syahputra (2007). Vermicompost fertilizer provides a good contribution to plants and can provide nutrients and other compounds so that plants can be utilized to increase the fresh stover weight (Siswanto, 2004).

\section{Dry stover weight}

Analysis of quadratic regression between vermicompost dose and had a noticeable effect, shown by the $\mathrm{R}^{2}$ coefficient value of 0.543 , which means that the increased dose of vermicompost then the more and the better plant growth.

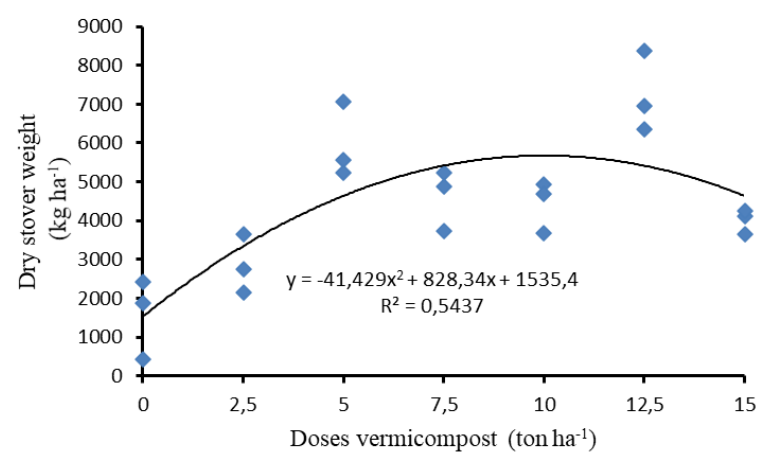

Figure 5. Relationship between doses of vermicompost fertilizer and dry stover weight

The optimum dose of vermicompost 9.9 tons $\mathrm{ha}^{-1}$ produces an optimum of 5,675.5 $\mathrm{kg}$ ddry stover weight $\mathrm{ha}^{-1}$. In a similar study conducted by Libra (2018) the dose of vermicompost fertilizer of 10 tons $\mathrm{ha}^{-1}$ produced a dry stover weight of $64.6 \mathrm{~g}$ of a plant. Herlina (2016) also conducted a similar study with a dose of vermicompost fertilizer of 10 tons ha ${ }^{-}$ ${ }^{1}$ resulting in a of $3.71 \mathrm{~g}$ of a plant. From the results of this study, giving doses of vermicompost gives a very real influence on and can increase the absorption of nutrients in the soil to improve the physical, chemical, and biological properties of soil (Sirappa \& Razak, 2010).

\section{Root dry weight}

Analysis of quadratic regression between vermicompost dose and root dry weight has a real effect and can be proven by the coefficient value of $\mathrm{R}^{2}=$ 0.406 .

The optimum dose of vermicompost 9.5 tons $\mathrm{ha}^{-1}$ produces a root dry weight optimum of $1,156 \mathrm{~kg}$ $\mathrm{ha}^{-1}$. While the research conducted by Libra (2018) with the provision of vermicompost fertilizer 10 tons $\mathrm{ha}^{-1}$ produces a dry weight of optimum roots $11.34 \mathrm{~g}$ 
polybags $^{-1}$. From the results of this study, giving a dose of vermicompost 9.5 tons $\mathrm{ha}^{-1}$ provides nutrients in the soil to increase the weight of roots in corn crops. Plants need nutrients to carry out metabolic processes, especially in vegetative times used to encourage cell division, and form plant organs such as at the root (Gardner et al., 1991). According to Havlin et al. 2005 , with the availability of nutrients in the soil, the root growth condition is getting bigger, the root growth is also getting better, the roots in plants serve to absorb water and store food parts needed by plants.

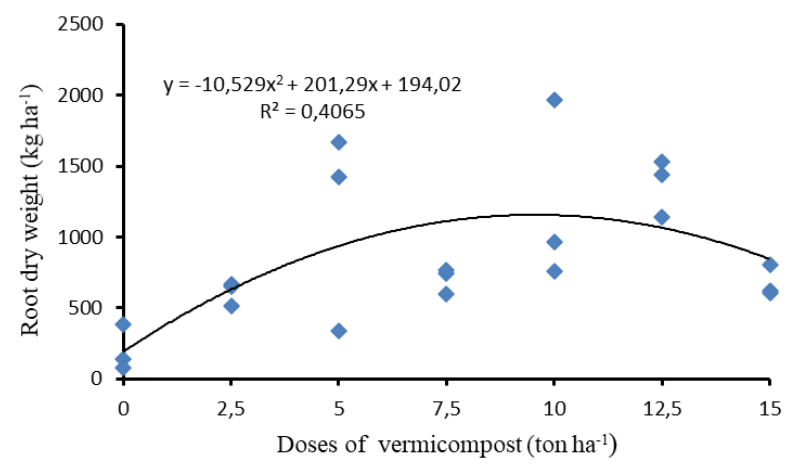

Figure 6. Relationship between doses of vermicompost fertilizer and root dry weight

\section{CONCLUSION}

Optimum vermicompost dose of 5.71 tons $\mathrm{ha}^{-1}$ gives maximum results for $\mathrm{K}$ levels of $0.59 \%$, and the optimum dose of 9.5 tons $\mathrm{ha}^{-1}$ gives maximum results for uptake $\mathrm{K} 31 \mathrm{~kg} \mathrm{ha}^{-1}$. While the optimum dose of vermicompost fertilizer 9.59 tons $\mathrm{ha}^{-1}$ gives maximum results to plant height of $160.7 \mathrm{~cm}$, the optimum dose of vermicompost fertilizer 10.2 tons $\mathrm{ha}^{-1}$ provides a maximum yield for fresh stover weight $27,561.2 \mathrm{~kg}$ $\mathrm{ha}^{-1}$. Vermicompost dose of 9.9 tons ha ${ }^{-1}$ gives maximum yield for dry stover weight $5,675.5 \mathrm{~kg} \mathrm{ha}^{-1}$, and the optimum dose of vermicompost 9.5 tons ha $^{-1}$ gives maximum yield for the root dry weight of $1,156 \mathrm{~kg}$ $\mathrm{ha}^{-1}$.

\section{References}

Ayunda. N. (2014). Pertumbuhan dan hasil jagung (Zea mays, L.) pada beberapa konsentrasi mineral. Skripsi. Fakultas Pertanian, Universitas Taman Siswa, Padang .

BPPP. (2008). Teknologi Budidaya Jagung. Badan Penelitian dan Pengembangan Pertanian, Jakarta.

Direktorat Jenderal Tanaman Pangan. (2015). Buku Pedoman GP-PTT Jagung, Jakarta.

Gardner, Franklin, P. B. Pearce, R. Roger, L. Mitchell. (1991). Physiologi of Crop Plant. diterjemahkan oleh Herawati Susilo. Fisiologi Tanaman Budidaya. UI-Press.,Jakarta.
Hartatik, W., D. Setyorini, L. R.Widowati \& Widati, S. (2005). Laporan Akhir PenelitinTeknologi Pengelolaan Hara pada Budidaya Pertanian Organik. Laporan Bagian Proyek Penelitian Sumberdaya Tanah dan Proyek Pengkajian Teknologi Pertanian, Bogor.

Havlin, J. L., Beaton, J. D., Tisdale, S. L \& Nelson, W. L. (1999). Soil Fertility and Fertilizers an Introduction to Nutrient Management. $6^{\text {th }}$ ed. Prentice-Hall, Upper Saddle River,New Jersey.

Herlina, C.N. (2016). Efektivitas dosis pupuk vermi kompos terhadap pertumbuhan dan hasil tanaman kedelai (Gyicine max L. Merril) pada tanah Ultisols Jantho. Jurnal Floratek, 11(1),1-9.

Kasno, A. \& Rostam, T. (2013). Serapan hara dan peningkatan produktivitas jagung dengan aplikasi pupuk NPK majemuk. Badan Pusat Penelitian Petanian Tanaman Pangan, 32(3), 179-186.

Kementerian Pertanian. (2015). Outlook Komoditas Pertanian Subsektor Tanaman Pangan Jagung. Pusdatin Kementerian Pertanian, Jakarta. (in Indonesian).

Libra, N.I. (2018). Pengaruh aplikasi vermikompos dan pupuk anorganik terhadap serapan hara dan kualitas hasil jagung manis (Zea mays L). Jurnal Folium, 1(2), 43-53.

Mulat, T. (2005). Membuat dan Memanfaatkan Kascing Pupuk Organik Berkualitas. Agromedia Pustaka, Jakarta.

Nazar, A. (2006). Karakter agronomi 16 genotipe jagung hibrida berumur dalam. J.Akta Agrosia. 9(2), 67-74.

Page, A. L., Miller, R.H. \& Keeney, D.R. (1982). Methods of Soil Analysis Part 2 Chemical and Microbiological Properties Second Ed. Number 9 (Part 2) in the series Agronomi. Amer. Soc. Agronomy, Soil Sci. Soc. Amer. Publ. Madison, USA.

Pradipta, R., Wicaksono, K.P. \& Guritno, B. (2014). Pengaruh umur dan pemberian berbagai dosis pupuk kalium terhadap pertumbuhan dan kualitas jagung. Jurnal Produksi Tanaman, 2 (7), 595-599.

Prasetyo, B. H. N. \& Suriadikarta, H. (2006). Karakteristik dan sebaran Ultisol di daerah Pameti karata. Jurnal Tanah dan Iklim, (37), 277-283.

Riwandi, Handajaningsih, M., Hasanudin\& Munawar, A. (2015). Soil quality improvement using compost and its effects on organic corn production. J Trop Soils, 20(1), 11-19.

Riwandi, Handajaningsih, M. \& Hasanudin. (2014). Tehnik Budidaya Jagung dengan Sistem Organik di Lahan Marjinal. Cetakan pertama UNIB Press., Bengkulu.

Roidah, I. S. (2013). Manfaat penggunaan pupuk organik untuk kesuburan tanah. Jurnal Universitas Tulung Agung, Bonorowo.1(1), 30-43. 
Salisbury, F.B. \& Ross, C.W. 1995. Fisiologi Tumbuhan Jilid 2. Diterjemahkan oleh Lukman, D.R. dan Sumaryono. ITB Press., Bandung.

Sallaku G., Babaj, I., Kalsium, S. \& Balliu, A. (2009). The influence of vermicompost, plant growth characteristics of cucumber (Cucumis sativus L.) seedlings under saline conditions. J. Food Agric. Environment, 7(34), 869-872.

Sheela. S. \& Khimiya, S. (2013). Vermicompost to save our agriculture land. Res. J Agriculture and Forestry Sci.. 1(4), 18-20.

Sirappa, M. P. \& Razak, N. (2010). Peningkatan Produktivitas Jagung Melalui Pemberian Pupuk N, P, K dan Pupuk Kandang pada Lahan Kering di Maluku. Prosiding Pekan Serelia Nasional.

Siswanto, U, Sukarjo E.I. \&Risnaily.(2004). Respon tanaman jagung manis (Zea mays L.) pada lahan marjinal dan menggunakan berbagai takaran dan aplikasi vermikompos. J. Ilmuilmu Pertanian Indonesia, 6(2), 83-90.
Soil Survey Staff. (2014). Key to Soil Taxanomy, 12th ed. USDA-Natural Resources Conservation Service, Washington, DC.

Sulaiman, Suparto \& Eviati. (2005). Analisis Kimia Tanah, Tanaman, Air, dan Pupuk. Bogor. Balai Penelitian Tanah. (in Indonesian). http:// balittanah.litbang.deptan.go.id.

Syahputra, D. F. (2007). Efek residu pupuk organik terhadap produksi sawi (Brassia junsea L) dan beberapa sifat kimia tanah Andisol. Skripsi. Fakultas Pertanian Universitas Sumatera Utara, Medan.

Tauri, D. (2014). Penampilan agronomis 20 varietas jagung pada sistem pertanian organik. Skripsi. Fakultas Pertanian, Universitas Bengkulu, Bengkulu.

Wibawa. W. (2014). Sasaran Luas Tanam, Luas Panen, Produksi dan Produktivitas Tanaman Pangan Tahun 2014 Kabupaten Kota Provinsi Bengkulu. Balai Pengkajian Teknologi Pertanian Bengkulu, Bengkulu. 